\title{
Quality characteristics of Cheonggukjang by mixed culture of biogenic amine producing- and degrading-bacteria
}

\author{
Eun-Seo Lim ${ }^{1 *}$, Eun-Woo Lee ${ }^{2}$ \\ ${ }^{1}$ Department of Food Science \& Nutrition, Tongmyong University, Busan 48520, Korea \\ ${ }^{2}$ Department of Life Science and Biotechnology, Dogeui University, Busan 47340, Korea

\section{바이오제닉 아민 생성 및 분해균의 혼합 배양으로 제조한 청국장의 품질 특성} \\ 임은서 ${ }^{1 *} \cdot$ 이은우 ${ }^{2}$ \\ ${ }^{1}$ 동명대학교 식품영양학과 ${ }^{2}$ 동의대학교 생명응용학과
}

\begin{abstract}
The objective of this study was to evaluate biogenic amine (BA) formation and degradation abilities of Bacillus strain and lactic acid bacteria (LAB) isolated from meju and doenjang and to determine the microbiological and physicochemical qualities of Cheonggukjang prepared by mixed culture of these strains. Accumulation of cadaverine $(421.7 \pm 11.0 \mathrm{mg} / \mathrm{L})$ and histamine $(628.7 \pm 24.1 \mathrm{mg} / \mathrm{L})$ was assessed in the culture media of Bacillus subtilis MJ226 that displayed lysine and histidine decarboxylase activities. No ability to form cadaverine, histamine, putrescine, tyyptamine, and tyramine by Lactobacillus acidophilus D11, L. acidophilus D38, Lactobacillus sakei D44, Lactobacillus plantarum D70, which exhibited high BA degradation ability. The amino nitrogen and free amino acid contents were significantly $(p<0.05)$ increased in Cheonggukjang prepared by the mixed culture of LAB (L. sakei D44, $L$. plantarum D70, or $L$. pentosus D74) and B. subtilis MJ226, whereas the ammonia nitrogen and BA (cadaverine and histamine) contents were significantly $(\mathbf{p}<0.05)$ decreased. Consequently, it was confirmed that BA formation in Cheonggukjang prepared by starter culture of $B$. subtilis was effectively inhibited by the certain strains of LAB having BA-degrading ability.
\end{abstract}

Key words : Bacillus, biogenic amine, Cheonggukjang, lactic acid bacteria

\section{서 론}

바이오제닉 아민(biogenic amine, BA)은 식품의 발효나 저장 과정 중에 미생물의 작용에 의해 생성되는 독성 물질 로서 사람이나 동물의 신경과 혈관을 자극하여 식중독과 유사한 증상을 유발한다. 식품 내에서 주로 검출되는 BA로 는 푸트레신(putrescine), 카다베린(cadaverine), 베타-페닐 에틸아민(ß-phenylalanine), 티라민(tyramine), 스페르민

*Corresponding author. E-mail : limsm020@tu.ac.kr;

Phone : 82-51-629-1714, Fax : 82-51-629-1709

Received 27 June 2019; Revised 01 August 2019; Accepted 01 August 2019.

Copyright (c) The Korean Society of Food Preservation. All rights reserved. (spermine), 히스타민(histamine), 스페르미딘(spermidine), 트립타민(tryptamine) 및 아그마틴(agmatine) 등이며, 이들 은 주로 생선, 육류, 난류, 치즈, 채소, 맥주 및 와인 등에서 고농도가 검출된다. $\mathrm{BA}$ 는 고온, 냉동 및 훈연 처리 시에도 쉽게 분해되지 않으며, 아질산염과 BA가 혼재할 경우 암을 유발하는 니트로사민을 형성하게 된다 $(1,2)$.

단백질 함량이 높은 콩을 원료로 제조하는 된장은 발효 과정 동안 다양한 미생물들의 프로테아제에 의해 단백질은 저분자 펩타이드, 아미노산 및 암모니아로 분해되고 디카 르복실라아제에 의해 아미노산의 카르복실기가 제거됨으 로써 다량의 $\mathrm{BA}$ 가 생성된다(3). 비록 미생물의 종류에 따라 디카르복실라아제의 합성 능력은 서로 다르지만, 대부분의 대두 발효 및 비 발효 식품은 BA가 합성될 수 있는 조건 하에서 제조된다(4). 특히 장내 미생물이나 부패 세균들의 
강한 디카르복실라아제의 활성에 의해 많은 양의 히스타 민, 푸트레신 및 카다베린이 생성되므로 $\mathrm{BA}$ 의 함량은 비위 생적인 품질 판정에 이용된다(5). 디카르복실라아제 효소 를 생성하는 세균으로는 Bacillus, Citrobacter, Clostridium, Klebsiella, Escherichia, Proteus, Pseudomonas, Salmonella, Shigella, Photobacterium, Lactobacillus, Pediococcus 및 Streptococcus sp. 등이 알려져 있다(3). 특히 된장으로부터 분리된 Clostridium, Pseudomonas, Staphylococci, Bacillus sp. 및 유산균 등으로부터 강한 디카르복실라아제 활성이 확인되었고, 이들은 티라민, 히스타민, 카다베린 및 푸트레 신 등의 $\mathrm{BA}$ 생성능이 큰 것으로 나타났다(6).

일본식 전통 발효 된장인 미소(miso)로부터 분리된 Enterococcus faecium, Lactobacillus bulgaricus는 티라민을 생성하였고, Lactobacillus sp.와 Lactobacillus sanfrancisco 는 히스티딘 디카르복실라아제를 생성하는 것으로 밝혀졌 으며(7), Lactobacillus curvatus, Lactobacillus carnis, Lactobacillus divergens 및 Lactobacillus hilgardii 등도 BA 생성균으로 확인되었다(8). 대두 발효 식품 내에서 $\mathrm{BA}$ 는 발효 과정 동안 활성이 높게 유지되고 아미노산 이용능이 우수한 유산균에 의해 주로 생성되는데 균종이나 균주에 따라 $\mathrm{BA}$ 의 종류 및 생성량에 큰 차이가 있으며, 제조 환경, 원료 내 대두의 비율, 발효 조건 및 저장 기간에 따라 $\mathrm{BA}$ 의 양은 크게 달라진다(2,9).

반면, Garcia-Ruiz 등(10)은 Lactobacillus casei, L hilgardii, Pediococcus parvulus, Oenococcus oeni, Lactobacillus plantarum 및 Pediococcus pentosaceus 등은 유의할 만한 수준의 히스타민, 티라민 및 푸트레신을 분해할 수 있는 활성을 나타내었다고 보고하였다. Capozzi 등(11)도 $L$. plantarum 2균주가 푸트레신과 티라민을 분해하는 것으로 확인되어 와인 발효용 스타터로 이용할 경우 BA 저감화에 효과적일 것이라고 고찰하였다. $\mathrm{BA}$ 분해능을 가진 유산균 은 아민 산화 효소(amine oxidase)에 의해 BA를 산화시켜 알데히드, 과산화수소 및 암모니아로 전환시켜 주므로 식 품 내 BA 함량을 낮춘다(12). 게다가 유산균은 BA 생성균 의 증식을 억제시킬 수 있는 항균 물질을 생산하므로 유해 균으로 인한 위험을 제어하기 위한 수단으로 식품 제조 산업 분야에서 식품의 안전성 향상 및 저장 기간 연장을 위한 생물학적 보존제로서 활용되기도 한다(13). 박테리오 신을 생성하는 유산균은 치즈 내 히스타민 생성을 억제하는 데 효과적이었고(14), 멸치 젓갈로부터 분리된 히스타민 생성균에 대해서도 박테리오신 생성 유산균의 항균 효과가 나타났다(15).

하지만, 대두 발효 식품의 주요 스타터인 일부 바실러스 균이나 유산균은 프로바이오틱 균주로서 혈전 용해, 항암, 항산화 및 항균 등 다양한 생리활성을 발휘하기는 하나, 발효 과정 중 원료에 풍부하게 함유된 단백질을 분해함으로 써 독성 물질인 $\mathrm{BA}$ 를 생성함에 따라 중독 발생 위험이
크다. 따라서 본 연구에서는 메주와 된장으로부터 분리된 바실러스균과 유산균의 균주별 $\mathrm{BA}$ 생성 및 분해능을 측정 하고 바실러스균과 $\mathrm{BA}$ 분해 유산균과의 혼합 배양을 통해 청국장의 미생물학적 및 물리화학적 특성과 $\mathrm{BA}$ 생성량의 변화를 조사하였다.

\section{재료 및 방법}

\section{사용 균주 및 배양}

전보(16-18)에서 메주로부터 분리된 Bacillus subtilis $\mathrm{MJ}-226$ 과 된장에서 분리된 유산균(Enterococcus faecalis D08, Lactobacillus acidophilus D11, E. faecium D12, Pediococcus acidilactici D19, P. pentosaceus D21, Leuconostoc mesenteroides D23, Lactobacillus fermentum D37, L. acidophilus D38, Lactobacillus sakei D44, Pediococcus halophilus D49, E. faecalis D51, $L$. mesenteroides subsp. mesenteroides D59, L. fermentum D60, E. faecalis D66, L. plantarum D70, Lactobacillus pentosus D74, Lactobacillus rhamnosus D78, Leuconostoc sp. D82, Enterococus casseliflavus D86)을 대상으로 BA 생성 및 분해 능을 조사하였다. 실험 균주는 Lactobacilli MRS agar (BD Difco Co., Sparks, MD, USA) 사면배지 상에서 계대 배양(3 $7^{\circ} \mathrm{C}, 24$ 시간)하여 사용하였다.

\section{$\mathrm{BA}$ 생성능 측정}

실험 균주의 효소 생성을 유도하기 위해 탈카르복시화 액체배지에 전구체 아미노산(1-arginine monohydrochloride, 1-histidine monohydrochloride monohydrate, 1-lysine monohydrochloride, 1-ornithine monohydrochloride, 1-phenylalanine, 1-tryptophan 및 1-tyrosine hydrochloride, Sigma-Aldrich, St. Louis, MO, USA, $1 \mathrm{~g} / \mathrm{L}$ )과 pyridoxal 5 -phosphate $(1 \mathrm{mg} / \mathrm{L})$ 를 첨가한 다음 균 접종 후 $37^{\circ} \mathrm{C}$ 에서 48 시간 동안 5 회 전 배양하였다. Microtiter plate의 well에 전 배양액 $(50 \mu \mathrm{L})$ 과 아미노산 $(2 \%, \mathrm{w} / \mathrm{v})$ 이 첨가된 탈카르복 시화 액체배지 $(100 \mu \mathrm{L})$ 를 각각 분주한 후 $35^{\circ} \mathrm{C}, 72$ 시간 동안 혐기적인 조건(Anoxomat system, MART Co., BV, Netherlands)에서 배양한 다음 BA 함량은 Eerola 등(19)과 $\mathrm{Mah}$ 등(20)의 방법을 일부 변형하여 측정하였다. 배양액을 원심분리 $\left(7,000 \times \mathrm{g}, 10\right.$ 분, $\left.4^{\circ} \mathrm{C}\right)$ 한 후 상등액 $(1 \mathrm{~mL})$ 을 여과 제균 $(0.22 \mu \mathrm{m}$ membrane filter, Millipore Co.)한 다음 BA 혼합 표준용액(cadaverine, histamine, putrescine, tyramine, tryptamine, $500 \mathrm{mg} / \mathrm{L}$ )과 $0.4 \mathrm{M}$ perchloric acid (Merck, Kenilworth, NJ, USA, $9 \mathrm{~mL}$ )를 첨가하였다. 진탕 혼합 후 원심분리 $(3,000 \times \mathrm{g}, 10$ 분 $)$ 해서 회수한 상등액은 여과 (Whatman paper No. 1, Piscataway, NJ, USA)한 다음 여액(1 $\mathrm{mL})$ 에 $2 \mathrm{~N}$ sodium hydroxide $(200 \mu \mathrm{L})$ 와 sodium bicarbonate 
포화 용액 $(300 \mu \mathrm{L})$ 을 가하고 acetone에 용해시킨 dansyl chloride (Sigma-Aldrich, $10 \mathrm{mg} / \mathrm{mL}$ ) $2 \mathrm{~mL}$ 를 첨가하였다. $40^{\circ} \mathrm{C}$ 에서 약 45 분간 반응시킨 다음 잔존하는 dansyl chloride는 $25 \%$ ammonium hydroxide $(100 \mu \mathrm{L})$ 를 가하여 제거하고 상온에 방치하였다. 약 30 분 경과 후 acetonitrile을 가하여 최종 $5 \mathrm{~mL}$ 로 맞추고 원심분리 $(2,500 \times \mathrm{g}, 5$ 분 $)$ 해서 얻은 상등액은 여과 $(0.22 \mu \mathrm{m}$ membrane filter)하여 dansyl 유도체화 시켰다. High pressure liquid chromatography (HPLC, Shimadzu, Kyoto, Japan)의 Nova-Pak $\mathrm{C}_{18}$ column $(150 \times 3.9 \mathrm{~mm}$, Waters), Milford, MA, USA)을 사용하였으며 $\mathrm{UV} 254 \mathrm{~nm}$ 에서 검출하였다. 컬럼 온도 $40^{\circ} \mathrm{C}$ 에서 이동상 (solvent A: $0.1 \mathrm{M}$ ammonium acetate, solvent B: acetonitrile) 의 유속은 $1 \mathrm{~mL} / \mathrm{min}$ 로 조정하였고, 시료량은 $10 \mu \mathrm{L}$ 로 주입 하였다.

\section{$\mathrm{BA}$ 분해능 측정}

바이오제닉 아민 분해능은 Lee 등(21)의 방법을 일부 변 형하여 측정하였다. 즉, 유산균은 MRS broth (BD Difco Co., Sparks, $\mathrm{MD}, \mathrm{USA})$ 에 접종하여 배양 $\left(37^{\circ} \mathrm{C}, 24\right.$ 시간)액을 원심분리 $\left(7,000 \times \mathrm{g}, 10\right.$ 분, $\left.4^{\circ} \mathrm{C}\right)$ 해서 세포를 모아 phosphate buffer saline (PBS, pH 7.0)으로 2회 세척하였다. 초기 균수 $1.0 \times 10^{6} \mathrm{CFU} / \mathrm{mL}$ 로 맞춘 세포 현탁액 $(1 \mathrm{~mL})$ 은 $\mathrm{BA}$ (cadaverine dihydrochloride, histamine dihydrochloride, putrescine dihydrochloride, tryptamine hydrochloride, tyramine hydrochloride, $0.1 \%, \mathrm{w} / \mathrm{v})$ 을 첨가한 액체배지 [glucose $0.1 \%(\mathrm{w} / \mathrm{v})$, yeast extract $0.2 \%(\mathrm{w} / \mathrm{v}), \mathrm{NaCl} 0.5 \%$ $(\mathrm{w} / \mathrm{v}), \mathrm{K}_{2} \mathrm{HPO}_{4} 0.05 \%(\mathrm{w} / \mathrm{v}) ; \mathrm{pH} 7.0,10 \mathrm{~mL}$ )에 접종한 후 $35^{\circ} \mathrm{C}, 5$ 일간 배양하였다. 배양액 $(0.1 \mathrm{~mL})$ 은 $\mathrm{BA}(2 \%, \mathrm{w} / \mathrm{v})$ 가 첨가된 평판배지에 도말 접종하여 $30^{\circ} \mathrm{C}, 5$ 일간 배양하였다. 독립 집락을 선택하여 Trypticase Soy Agar (TSA, BD Difco Co., Sparks, MD, USA) 상에서 순수 분리한 다음 BA (50 $\mathrm{ppm}$ )가 첨가된 Trypticase Soy Broth (TSB, BD Difco Co., Sparks, $\mathrm{MD}, \mathrm{USA}$ )에 접종하고 $35^{\circ} \mathrm{C}$ 에서 24 시간 동안 배양 하였다. 배양액 $(1 \mathrm{~mL})$ 에 $\mathrm{BA}$ 혼합 표준용액 $(500 \mathrm{mg} / \mathrm{L})$ 및 $0.4 \mathrm{M}$ perchloric acid $(9 \mathrm{~mL})$ 를 가하고 진탕 혼합한 후 원심 분리 $(3,000 \times \mathrm{g}, 10$ 분)하였다. 상등액을 여과(Whatman paper No. 1)하고 앞서 언급한 방법에 따라 dansyl chloride로 유도 체화 한 후에 HPLC로 잔존하는 BA 함량을 측정하였다. 분해능(\%)은 식[(A-B)/A×100, $\mathrm{A}$ : 초기 $\mathrm{BA}$ 함량, $\mathrm{B}$ : 잔존하 는 $\mathrm{BA}$ 함량]에 대입하여 계산하였다.

\section{청국장 제조}

종균으로는 B. subtilis MJ226단독(대조구) 혹은 $\mathrm{BA}$ 분해 유산균과 혼합하여 청국장을 제조하였다. 바실러스균과 유 산균은 Brain Heart Infusion (BHI) broth (BD Difco Co., Sparks, MD, USA)와 MRS broth (BD Difco Co., Sparks, $\mathrm{MD}, \mathrm{USA})$ 에 각각 접종하고 배양 $\left(37^{\circ} \mathrm{C}, 24\right.$ 시간) 후 얻은
배양액은 원심분리 $\left(7,000 \times \mathrm{g}, 10\right.$ 분, $\left.4^{\circ} \mathrm{C}\right)$ 하였다. 각각의 세 포를 PBS $\left(\mathrm{pH}\right.$ 7.0)로 세척하고 난 다음 균수를 $1.0 \times 10^{6}$ $\mathrm{CFU} / \mathrm{mL}$ 로 조정하였다. 한편, 수세한 대두(100 g)에 증류수 를 10 배 가한 후 24 시간 동안 침지하였다. 물기를 제거한 후 증자 $\left(121^{\circ} \mathrm{C}, 30\right.$ 분 $)$ 하고 나서 냉각 $\left(40-45^{\circ} \mathrm{C}\right)$ 한 다음 종균 현탁액 $1 \%(\mathrm{v} / \mathrm{w})$ 씩 각각 접종하고 $80 \%$ 의 습도 하에서 발효 $\left(37^{\circ} \mathrm{C}, 72\right.$ 시간 $)$ 시켜 제조하였다. 발효 종료 후 시료는 동결 건조 후 분쇄하여 실험에 사용하였다.

\section{생균수 측정}

시료 $(10 \mathrm{~g})$ 에 증류수 $(90 \mathrm{~mL})$ 를 가하여 stomacher $(3 \mathrm{M}$, St. Paul, MN, USA)로 약 3분간 균질화하고 $\mathrm{PBS}(\mathrm{pH}$ 7.0)로 십진 희석한 시료 $(1 \mathrm{~mL})$ 내 바실러스균과 유산균수는 각각 Luria-Bertani (LB, BD Difco Co., Sparks, MD, USA)와 MRS agar (BD Difco Co., Sparks, MD, USA) 평판 배지 상에서 표준한천평판배양법으로 측정한 다음 집락수를 계수하여 $\mathrm{CFU} / \mathrm{g}$ 으로 표시하였다.

\section{$\mathrm{pH}$ 측정}

시료 $(10 \mathrm{~g})$ 에 증류수 5 배를 가하고 스토마커로 균질화 한 다음 원심분리 $(7,000 \times \mathrm{g}, 10$ 분 $)$ 해서 얻은 상등액을 시료 액으로 하여 $\mathrm{pH}$ meter (Fisher Scientific, Waltham, MA, USA)로 측정하였다.

\section{적정 산도 측정}

시료 $(5 \mathrm{~g})$ 에 동량의 증류수를 가하고 $1 \%(\mathrm{w} / \mathrm{v})$ 페놀프탈 레인 지시약을 첨가한 다음 $0.1 \mathrm{~N} \mathrm{NaOH}$ 용액으로 적정하여 그 소비량을 측정한 다음 계산식[산도(\%) $=0.1 \mathrm{~N} \mathrm{NaOH}$

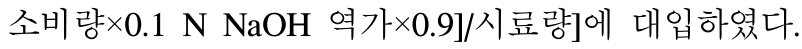

\section{단백질 가수분해 효소 활성 측정}

멸균 증류수 $(100 \mathrm{~mL})$ 에 시료 $(2.5 \mathrm{~g})$ 을 가하여 항온수조 $\left(37^{\circ} \mathrm{C}\right)$ 에서 4 시간 동안 진탕 $(150 \mathrm{rpm})$ 한 다음 원심분리 $(4,000 \times \mathrm{g}, 15$ 분 $)$ 하여 얻은 상등액을 효소액으로 사용하였 다. 시료 $(0.05 \mathrm{~mL})$ 에 동량의 $2 \%$ azocasein $(0.2 \mathrm{M}$ Tris- $\mathrm{HCl}$, $\mathrm{pH}$ 7.5)을 가하여 혼합한 후 항온수조 $\left(40^{\circ} \mathrm{C}\right)$ 내에서 20 분간 반응시킨 다음 $10 \%$ trichloroacetic acid $(0.05 \mathrm{~mL})$ 를 첨가하 고 얼음 안에서 약 10 분간 방치하여 반응을 정지시켰다. 원심분리 $(6,000 \times \mathrm{g}, 20$ 분 $)$ 하여 얻은 상등액 $(0.15 \mathrm{~mL})$ 에 $2 \mathrm{~N}$ Folin phenol reagent $(0.3 \mathrm{~mL})$ 와 $\mathrm{Na}_{2} \mathrm{CO}_{3}(0.45 \mathrm{~mL})$ 를 첨가한 후 $30^{\circ} \mathrm{C}$ 항온 수조 내에서 2 차 반응시켜 발색된 시료를 $660 \mathrm{~nm}$ 에서 흡광도를 측정하였다. 효소 1 unit는 1 분당 1 $\mu \mathrm{M}$ 의 tyrosine을 생성하는 효소양으로 정의하였다(22).

\section{아미노태 질소 함량 측정}

Formol 적정법(23)으로 측정하기 위해 시료 $(5 \mathrm{~g})$ 에 멸균 증류수 $(50 \mathrm{~mL})$ 를 가하여 약 30 분간 교반시켰다. 시료 용액 
은 원심분리 $(10,000 \times \mathrm{g}, 15$ 분 $)$ 한 다음 $0.45 \mu \mathrm{m}$ syringe filter 로 여과한 여액 $(10 \mathrm{~mL})$ 에 $0.1 \%$ 페놀프탈레인 지시약을 첨 가한 후 $0.1 \mathrm{~N} \mathrm{NaOH}$ 표준용액으로 미홍색이 될 때까지 적정하였다. 그런 다음 포르말린 용액(35-40\%) $20 \mathrm{~mL}$ 를 첨가한 후 $\mathrm{pH}$ 8.3이 될 때까지 소요된 $0.1 \mathrm{~N} \mathrm{NaOH}$ 표준용액 의 양으로 아미노태 질소 함량을 계산하였다.

\section{암모니아태 질소 함량 측정}

암모니아태 질소 중화적정법(24)으로 측정하기 위해 시 료 $(5 \mathrm{~g})$ 에 증류수를 가하고 혼합 진탕한 후 거즈로 여액과 대두를 분리하였다. 여액을 원심분리 $(10,000 \times \mathrm{g}, 10$ 분 $)$ 하고 상등액 $(20 \mathrm{~mL})$ 를 취하여 시료 용액으로 사용하였다. $4 \%$ $\mathrm{NaOH}$ 용액 $(0.7 \mathrm{~mL})$ 을 첨가한 후 산화마그네슘 $(0.3 \mathrm{~g})$ 과 비등석을 넣고 증류수로 최종 $150 \mathrm{~mL}$ 로 맞춘 후 증류하였 다. $0.05 \mathrm{~N}$ 황산용액 $25 \mathrm{~mL}$ 를 넣은 수기에 증류액 약 70 $\mathrm{mL}$ 정도 모은 후 증류수로 $100 \mathrm{~mL}$ 정용하였다. 메틸레드브롬크레졸그린 혼합 지시액 3-4방울을 넣은 다음 종말점 자회색(pH 4.8)이 나타날 때까지 소요된 $0.05 \mathrm{~N} \mathrm{NaOH}$ 용액 의 양을 구하여 암모니아태 질소의 농도를 계산하였다.

\section{유리 아미노산 함량 측정}

Rozan 등(25)의 방법에 따라 HPLC (Shimadzu, Kyoto, Japan)로 분석하였다. 즉, 아미노산 표준용액 $(20 \mu \mathrm{L})$ 과 시료 는 진공 $\left(37^{\circ} \mathrm{C}, 20 \mathrm{mmHg}\right)$ 하에서 20 분간 건조시켰다. 이에 메탄올, 물, 트리에틸아민은 2:2:1 (v/v) 비율의 용액을 첨가 한 후 혼합해서 다시 20 분간 진공 건조시켰다. 메탄올, 트리에 틸아민, 물, 페닐이소티오시아네이트(methanol, trimethylamine, water, phenylisocyanate, PITC)는 7:1:1:1 (v/v)의 비율로 첨가 한 유도체화 시료 $(20 \mu \mathrm{L})$ 를 첨가해서 약 20 분간 상온에서 반응시켰다. 그런 다음 시료 내 과도한 PITC를 제거하기 위해 20 분간 진공 하에서 건조시킨 유도체화 된 시료는 이동상 buffer $\mathrm{A}(100 \mathrm{~mL})$ 에 용해시켰다. Purospher STAR RP-18e 컬럼(Merck, Darmstadt, Germany)에 이동상 A (0.1 $\mathrm{M}$ ammonium acetate, $\mathrm{pH}$ 6.5)와 이동상 $\mathrm{B}(0.1 \mathrm{M}$ ammonium acetate : acetonitrile : methanol $=44: 46: 10, \mathrm{v} / \mathrm{v}, \mathrm{pH} 6.5)$ 의 유속 $1 \mathrm{~mL} / \mathrm{min}$ 로 시료 $20 \mu \mathrm{L}$ 를 주입하여 $254 \mathrm{~nm}$ 에서 분석 하였다.

\section{바이오제닉 아민 함량 측정}

Han 등(26)의 방법을 일부 변형하여 측정하였는데 시료 $(5 \mathrm{~g})$ 에 $0.1 \mathrm{~N} \mathrm{HCl}(20 \mathrm{~mL})$ 을 가한 후 균질화한 다음 원심분 리 $\left(7,000 \times \mathrm{g}, 20\right.$ 분, $\left.4^{\circ} \mathrm{C}\right)$ 하였다. 상등액을 회수하고 남은 잔사에 $0.1 \mathrm{~N} \mathrm{HCl}$ 를 가하여 반복 조작하여 상등액을 모두 합쳐 최종 $50 \mathrm{~mL}$ 에 맞춘 시료 용액을 유도체화 한 후에 앞서 설명한 조건으로 HPLC (Shimadzu, Kyoto, Japan)를 이용하여 바이오제닉 아민 함량을 측정하였다.

\section{통계분석}

실험 항목별로 각각 3회씩 실험하여 얻은 결과값은 평균 \pm 표준편차로 나타내었다. 실험 결과값은 SPSS 프로그램 (Ver. 12.0, Chicago, IL, USA)의 Student's t-test를 통해 $\mathrm{p}<0.05$ 유의 수준에서 대조구와 실험구의 유의성을 검정하 였다.

\section{결과 및 고찰}

\section{실험 균주의 $\mathrm{BA}$ 생성능}

탈카르복시화 액체배지 상에서 실험 균주들의 $\mathrm{BA}$ 생성 능을 조사한 결과는 Table 1 과 같다. 메주에서 분리된 $B$. subtilis MJ226은 카다베린 $(421 \pm 11.0 \mathrm{mg} / \mathrm{L})$ 및 히스타민 $(628.7 \pm 24.1 \mathrm{mg} / \mathrm{L})$ 을 생성하는 것으로 확인되었다. 한편, 된장으로부터 분리된 유산균의 $\mathrm{BA}$ 생성능을 조사한 결과, 카다베린은 E. faecalis D51 $(642.3 \pm 11.4 \mathrm{mg} / \mathrm{L})$, E. faecalis D66 $(255.6 \pm 9.9 \mathrm{mg} / \mathrm{L})$ 및 Leuconostoc sp. D82 (391.6 \pm 15.4 $\mathrm{mg} / \mathrm{L}$ )로부터 생성되었다. 히스타민은 E. faecalis D08 $(1,045.8 \pm 33.5 \mathrm{mg} / \mathrm{L})$ 과 E. faecalis D66 $(504.7 \pm 20.9 \mathrm{mg} / \mathrm{L})$ 으 로부터 검출되었고, 푸트레신은 E. faecalis D66 (912.4 \pm 6.7 $\mathrm{mg} / \mathrm{L}$ )만이 생성하는 것으로 확인되었다. 트립타민 생성균 은 E. faecium $\mathrm{D} 12(1,523.7 \pm 40.1 \mathrm{mg} / \mathrm{L})$ 와 E. faecalis $\mathrm{D} 51$ $(623.4 \pm 15.5 \mathrm{mg} / \mathrm{L})$ 이었고, 티라민은 E. faecalis D08 $(237.9 \pm 13.2 \mathrm{mg} / \mathrm{L})$ 과 $E$. faecium D12 $(661.4 \pm 25.0 \mathrm{mg} / \mathrm{L})$ 가 생성하는 것으로 확인되었다. 이상의 결과 실험 균주 중에 서 대부분의 Enterococcus sp.와 Leuconostoc sp.이 BA를 생성하는 것으로 확인되었고 유산균의 균주에 따라 생성하 는 $\mathrm{BA}$ 의 종류에 차이가 있었고 생성량도 상이하다는 것을 알 수 있었다.

$\mathrm{BA}$ 는 많은 그람양성 및 음성균에 의해 생산되는데 $O$. oeni, L. hilgardii, Lactobacillus fructivorans, P. parvulus, Lactobacillus brevis 등 다양한 유산균들로부터 아미노산의 카르복실기 제거 능력이 확인되었다. 또한 $L$. curvatus, $E$. faecalis, E. faecium, L. fermentum, Lactococcus lactis, Streptococcus thermophilus 및 Lactobacillus paracasei 등도 탈탄산 효소를 생산하여 식품 내에 BA 생성의 원인균으로 밝혀져(27) 본 연구 결과와 부분적으로 일치하였다.

Barbieri 등(28)에 따르면 히스타민과 카다베린은 $E$. faecium 및 $E$. faecalis가 생산하고 티라민은 E. faecium, $E$. faecalis, Enterococcus durans, Enterococcus hirae, E. casseliflavus 및 Enterococcus mundtii 등이 생산하는 것으로 확인되었으며, 푸트레신은 E. faecium, E. faecalis, E. durans, E. hirae, E. casseliflavus 및 E. mundtii 등이 생산하는 것으로 보고된 바 있어 본 연구 결과와 일부 일치하였다. 한편, Leuconostoc $\mathrm{sp}$.에 속하는 Leuconostoc carnosus, Leuconostoc gasicomitatum 및 Leuconostoc gelidum은 식품 
의 부패와 주로 관련이 있으며 일부는 아미노산의 탈탄산 반응에 관여하기도 하고, L. mesenteroides는 히스타민, 푸 트레신이나 티라민을 생성하기도 한다고 알려졌는데(28), 본 연구에서는 Leuconostoc sp. D82가 카다베린을 생성하였 다. parvulus, O. oeni, L. plantarum, P. pentosaceus는 히스타민, 티라민, 푸트레신의 분해력이 뛰어난 것으로 확인되었다 (10). Capozzi 등(11)에 의하면, L. plantarum NDT 26균주 중에서 $30.8 \%$ 는 푸트레신, $26.9 \%$ 는 티라민, $19.2 \%$ 는 히스 타민 및 $19.2 \%$ 는 카다베린을 분해할 수 있었고 유산균의

Table 1. Biogenic amine-producing ability of the tested strains in decarboxylase medium supplemented with amino acid

\begin{tabular}{|c|c|c|c|c|c|}
\hline \multirow{2}{*}{ Strain } & \multicolumn{5}{|c|}{ BA-producing ability $(\mathrm{mg} / \mathrm{L})$} \\
\hline & Cadaverine & Histamine & Putrescine & Tryptamine & Tyramine \\
\hline Bacillus subtilis MJ226 & $421.7 \pm 11.0$ & $628.7 \pm 24.1$ & ND & $\mathrm{ND}$ & $\mathrm{ND}$ \\
\hline Enterococcus faecalis D08 & $\mathrm{ND}$ & $1,045.8 \pm 33.5$ & ND & $\mathrm{ND}$ & $237.9 \pm 13.2$ \\
\hline Lactobacillus acidophilus D11 & $\mathrm{ND}$ & $\mathrm{ND}$ & ND & ND & ND \\
\hline Enterococcus faecium D12 & $\mathrm{ND}$ & $\mathrm{ND}$ & $\mathrm{ND}$ & $1,523.7 \pm 40.1$ & $661.4 \pm 25.0$ \\
\hline Pediococcus acidilactici D19 & $\mathrm{ND}$ & $\mathrm{ND}$ & ND & ND & ND \\
\hline Pediococcus pentosaceus D21 & $\mathrm{ND}$ & $\mathrm{ND}$ & $\mathrm{ND}$ & $\mathrm{ND}$ & $\mathrm{ND}$ \\
\hline Leuconostoc mesenteroides D23 & $\mathrm{ND}$ & $\mathrm{ND}$ & ND & ND & ND \\
\hline Lactobacillus fermentum D37 & $\mathrm{ND}$ & $\mathrm{ND}$ & $\mathrm{ND}$ & ND & $\mathrm{ND}$ \\
\hline Lactobacillus acidophilus D38 & $\mathrm{ND}$ & $\mathrm{ND}$ & $\mathrm{ND}$ & $\mathrm{ND}$ & $\mathrm{ND}$ \\
\hline Lactobacillus sakei D44 & $\mathrm{ND}$ & $\mathrm{ND}$ & ND & ND & ND \\
\hline Pediococcus halophilus D49 & ND & ND & ND & $\mathrm{ND}$ & $\mathrm{ND}$ \\
\hline Enterococcus faecalis D51 & $642.3 \pm 11.4$ & $\mathrm{ND}$ & ND & $623.4 \pm 15.5$ & ND \\
\hline Leuconstoc mesenteroides subsp. mesenteroides D59 & $\mathrm{ND}$ & $\mathrm{ND}$ & $\mathrm{ND}$ & ND & $\mathrm{ND}$ \\
\hline Lactobacillus fermentum D60 & ND & ND & ND & $\mathrm{ND}$ & ND \\
\hline Enterococcus faecalis D66 & $255.6 \pm 9.9$ & $504.7 \pm 20.9$ & $912.4 \pm 6.7$ & ND & $\mathrm{ND}$ \\
\hline Lactobacillus plantarum $\mathrm{D} 70$ & ND & ND & ND & $\mathrm{ND}$ & $\mathrm{ND}$ \\
\hline Lactobacillus pentosus D74 & $\mathrm{ND}$ & $\mathrm{ND}$ & ND & ND & ND \\
\hline Lactobacillus rhamnosus D78 & ND & $\mathrm{ND}$ & ND & ND & $\mathrm{ND}$ \\
\hline Leuconostoc sp. D82 & $391.6 \pm 15.4$ & $\mathrm{ND}$ & ND & $\mathrm{ND}$ & ND \\
\hline Enterococcus casseliflarus D86 & ND & ND & ND & ND & ND \\
\hline
\end{tabular}

Data are means \pm standard deviation (SD) from triplicate determinations.

ND, not detected.

\section{실험 균주의 $\mathrm{BA}$ 분해능}

실험 균주들의 $\mathrm{BA}$ 분해능을 측정한 결과는 Table 2 와 같다. 메주에서 분리된 B. subtilis $\mathrm{MJ} 226$ 은 $\mathrm{BA}$ 분해능을 나타내지 않았으나, 일부 유산균들로부터 $\mathrm{BA}$ 분해능이 확 인되었다. 카다베린 분해능은 L. sakei D44 (26.1 $\pm 5.5 \%)$ 와

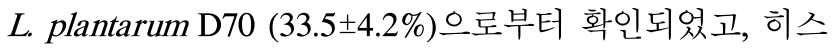
타민은 L. acidophilus D11 (12.9 $\pm 1.6 \%)$, L. acidophilus D38 $(19.1 \pm 2.2 \%)$ 및 L. pentosus D74 (42.3 $\pm 4.5 \%)$ 로부터 나타났 으며, L. acidophilus D11 (6.9 $\pm 1.8 \%)$ 은 티라민 분해능이 있는 것으로 확인되었으나, 푸트레신과 트립타민의 분해능 을 보인 실험 균주는 없었다. 따라서 유산균의 균주에 따라 분해할 수 있는 $\mathrm{BA}$ 의 종류가 다르고 분해능에도 상당한 차이가 있었다.

와인에서 분리된 Lactobacillus casei, L. hilgardii, P.
분해능은 균주에 의존하는 것으로 보고하였다. Kongkiattikajorn(29)도 L. urvatus KM2633 및 Leuconostoc mali $\mathrm{KM} 2725$ 에서는 $\mathrm{BA}$ 분해능이 확인되지 않았으나, Lactobacillus farciminis KM7642는 티라민(4.5\%) 분해능이 확인되었다. 게다가 L. plantarum KM5474는 트립타민 (2.1\%), 페닐에틸아민(3.5\%), 푸트레신(11.9\%), 카다베린 $(4.7 \%)$, 히스타민(6.9\%) 및 티라민(17.2\%) 등 다양한 BA 분해능이 나타났으며, Lactobacillus kandleri KM2416, L. sakei KM1450 및 Lactobacillus reuteri KM8124도 특정 BA 분해력이 있었다. L. plantarum, L. sakei, L. pentosus, P. acidilactici, Rhodococcus sp. Arthrobacter sp. Micrococcus sp. Brevibacterium linens 및 Geotrichum candidum 등은 아 민 산화 효소를 생성하여 티라민과 히스타민을 분해한다고 Leuschner 등(30)은 보고하였다. 이상 기존 문헌과 비교해 
볼 때 유산균의 균주에 따라 분해 가능한 BA 종류가 다르고 분해율에도 차이가 있음을 알 수 있었다.

아민 산화 효소는 생선 슬러리로부터 분리된 L. casei, L. plantarum, $L$ sakei에서도 확인되었고(27), 와인으로부터 분리된 $L$ plantarum IFI-CA 26, $P$. pentosaceus IFI-CA 30, IFI-CA 83 및 IFI-CA 86, P. parvulus IFI-CA 31, O. oeni IFI-CA 32, L. hilgardii IFI-CA 41, L. casei IFI-CA 52 및 L. plantarum IFI-CA 54에서도 강력한 히스타민, 티라민 및 푸트레신 분해능이 확인되었다(10). $L$ casei의 히스타민 과 티라민의 분해능도 아민 산화 효소 생성에 기인하였으며 이를 Cabrales 치즈에 이용한 경우 $\mathrm{BA}$ 축적량이 유의하게 감소되었다고 하여(27), 본 연구에서도 $\mathrm{BA}$ 분해능이 확인 된 유산균을 발효 스타터로 이용할 경우 식품 내 $\mathrm{BA}$ 저감화 에 효과적일 것으로 추정된다.
단독 배양 시 생균수는 $5.8 \pm 1.4 \times 10^{9} \mathrm{CFU} / \mathrm{g}$ 이었는데 $L$. acidophilus $\mathrm{D} 38, L$ plantarum $\mathrm{D} 70$ 및 L. pentosus $\mathrm{D} 74$ 와의 혼합 배양에 의해선 대조군과 비슷한 수준 혹은 다소 높은 균수가 검출된 반면, $L$ acidophilus D11 및 $L$ sakei D44와의 혼합 배양에 의해서 유의할 정도로 낮은 균수가 검출되었 다. 혼합 배양한 청국장에서 유산균의 균수는 바실러스균 과 비슷한 정도인 $10^{8}-10^{9} \mathrm{CFU} / \mathrm{g}$ 정도 측정되었다. 이상의 결과 유산균은 청국장 발효 과정 중에 증식하여 발효 완료 후 상당수의 균수가 검출되었는데 증식 정도는 유산균의 종류에 따라 다소 차이가 있었고 바실러스균의 증식에 미치 는 영향도 유산균의 균종에 따라 상이하였다. Ju (31)에 따르면 B. subtilis $\mathrm{CKB}$ 단독으로 청국장을 제조한 경우 초기 균수 $10^{6} \mathrm{CFU} / \mathrm{g}$ 이 12 시간 후 $10^{9} \mathrm{CFU} / \mathrm{g}$ 으로 증식하였 고, Brevibacterium breve ATCC 15700, L. mesenteroides

Table 2. Biogenic amine-degrading ability of the tested strains in trypticase soy broth supplemented with biogenic amines

\begin{tabular}{|c|c|c|c|c|c|}
\hline \multirow{2}{*}{ Strain } & \multicolumn{5}{|c|}{ Biogenic amines-degrading ability $(\%)$} \\
\hline & Cadaverine & Histamine & Putrescine & Tryptamine & Tyramine \\
\hline Bacillus subtilis MJ226 & ND & ND & $\mathrm{ND}$ & ND & ND \\
\hline Enterococcus faecalis D08 & $\mathrm{ND}$ & $\mathrm{ND}$ & $\mathrm{ND}$ & $\mathrm{ND}$ & ND \\
\hline Lactobacillus acidophilus D11 & $\mathrm{ND}$ & $12.9 \pm 1.6$ & $\mathrm{ND}$ & $\mathrm{ND}$ & $6.9 \pm 1.8$ \\
\hline Enterococcus faecium D12 & $\mathrm{ND}$ & ND & $\mathrm{ND}$ & $\mathrm{ND}$ & ND \\
\hline Pediococcus acidilactici D19 & $\mathrm{ND}$ & $\mathrm{ND}$ & $\mathrm{ND}$ & ND & ND \\
\hline Pediococcus pentosaceus $\mathrm{D} 21$ & ND & $\mathrm{ND}$ & $\mathrm{ND}$ & ND & ND \\
\hline Leuconostoc mesenteroides D23 & ND & $\mathrm{ND}$ & $\mathrm{ND}$ & ND & ND \\
\hline Lactobacillus fermentum D37 & ND & $\mathrm{ND}$ & $\mathrm{ND}$ & ND & ND \\
\hline Lactobacillus acidophilus D38 & $\mathrm{ND}$ & $19.1 \pm 2.2$ & $\mathrm{ND}$ & $\mathrm{ND}$ & $\mathrm{ND}$ \\
\hline Lactobacillus sakei D44 & $26.1 \pm 5.5$ & $\mathrm{ND}$ & $\mathrm{ND}$ & $\mathrm{ND}$ & $\mathrm{ND}$ \\
\hline Pediococcus halophilus D49 & $\mathrm{ND}$ & ND & $\mathrm{ND}$ & $\mathrm{ND}$ & $\mathrm{ND}$ \\
\hline Enterococcus faecalis D51 & $\mathrm{ND}$ & ND & $\mathrm{ND}$ & $\mathrm{ND}$ & $\mathrm{ND}$ \\
\hline Leuconstoc mesenteroides subsp. mesenteroides D59 & ND & $\mathrm{ND}$ & $\mathrm{ND}$ & $\mathrm{ND}$ & $\mathrm{ND}$ \\
\hline Lactobacillus fermentum D60 & $\mathrm{ND}$ & ND & $\mathrm{ND}$ & $\mathrm{ND}$ & ND \\
\hline Enterococcus faecalis D66 & $\mathrm{ND}$ & ND & $\mathrm{ND}$ & $\mathrm{ND}$ & $\mathrm{ND}$ \\
\hline Lactobacillus plantarum D70 & $33.5 \pm 4.2$ & ND & $\mathrm{ND}$ & $\mathrm{ND}$ & ND \\
\hline Lactobacillus pentosus D74 & $\mathrm{ND}$ & $42.3 \pm 4.5$ & ND & $\mathrm{ND}$ & ND \\
\hline Lactobacillus rhamnosus D78 & $\mathrm{ND}$ & $\mathrm{ND}$ & $\mathrm{ND}$ & ND & ND \\
\hline Leuconstoc sp. D82 & $\mathrm{ND}$ & $\mathrm{ND}$ & $\mathrm{ND}$ & $\mathrm{ND}$ & $\mathrm{ND}$ \\
\hline Enterococcus casseliflarus D86 & ND & ND & ND & ND & ND \\
\hline
\end{tabular}

Data are means \pm SD from triplicate determinations.

$\mathrm{ND}$, not detected.

바실러스균과 유산균의 혼합 배양으로 제조한 청국장의 품질 특성

$\mathrm{BA}$ 생성능이 있는 B. subtilis MJ226과 BA 분해능이 있는 유산균과의 혼합 배양을 통해 제조한 청국장 내 바실러스균 의 생균수를 측정한 결과는 Table 3 과 같다. 바실러스균
ATCC 9135 및 L. plantarum ATCC 8014 등의 유산균과 혼합 배양한 경우에는 바실러스균수가 초기 $10^{4} \mathrm{CFU} / \mathrm{g}$ 에서 12 시간 후 $10^{8} \mathrm{CFU} / \mathrm{g}$ 이었고, 유산균수는 $10^{6} \mathrm{CFU} / \mathrm{g}$ 에서 12 시간 후 $10^{7} \mathrm{CFU} / \mathrm{g}$ 으로 나타나 바실러스균에 비해 유산 균의 증식 속도가 늦은 것으로 나타났다. 이는 대두 성분이 
Table 3. Viable cell counts of fermentation starters in Cheonggukjang prepared by the mixed cultures of Bacillus subtilis MJ226 and biogenic amine-degrading lactic acid bacteria

\begin{tabular}{ccc}
\hline \multirow{2}{*}{$\begin{array}{c}\text { Biogenic amines-degrading lactic } \\
\text { acid bacteria }\end{array}$} & \multicolumn{2}{c}{ Viable cell counts (CFU/g) } \\
\cline { 2 - 3 } & Bacillus subtilis MJ226 & $\begin{array}{c}\text { Lactic acid } \\
\text { bacteria }\end{array}$ \\
\hline Control & $5.8 \pm 1.4 \times 10^{9}$ & $\mathrm{ND}$ \\
Lactobacillus acidophilus D11 & $7.7 \pm 5.4 \times 10^{8 *}$ & $4.6 \pm 0.2 \times 10^{8}$ \\
Lactobacillus acidophilus D38 & $6.3 \pm 0.8 \times 10^{9}$ & $6.6 \pm 2.0 \times 10^{8}$ \\
Lactobacillus sakei D44 & $2.6 \pm 0.6 \times 10^{8 *}$ & $3.8 \pm 0.1 \times 10^{9}$ \\
Lactobacillus plantarum D70 & $4.9 \pm 1.1 \times 10^{9}$ & $5.2 \pm 1.3 \times 10^{9}$ \\
Lactobacillus pentosus D74 & $8.2 \pm 2.5 \times 10^{9}$ & $2.7 \pm 3.0 \times 10^{9}$ \\
\hline
\end{tabular}

Data are means \pm SD from triplicate determinations.

"Significantly differ $(\mathrm{p}<0.05)$ from the control group by Student's t-test. $\mathrm{ND}$, not detected.

유산균보다 바실러스균 증식에 더욱 유리하고 바실러스균 의 단백질 분해 효소 활성이 높아서 생육이 촉진되거나 바실러스균의 항균 물질이 유산균의 증식을 방해하는 것으 로 추정하였다. 이와는 달리 본 연구에서는 바실러스균이 유산균의 증식에 유의할 만한 영향을 미치지는 않은 것으로 나타났다.

청국장의 $\mathrm{pH}$ 및 적정 산도를 측정한 결과는 Table 4와

Table 4. $\mathrm{pH}$ and titratable acidity of Cheonggukjang prepared by the mixed cultures of $B$. subtilis MJ226 and biogenic amine-degrading lactic acid bacteria

\begin{tabular}{ccc}
\hline $\begin{array}{c}\text { Biogenic amines-degrading lactic } \\
\text { acid bacteria }\end{array}$ & $\mathrm{pH}$ & Titratable acidity (\%) \\
\hline Control & $6.92 \pm 0.20$ & $0.21 \pm 0.02$ \\
Lactobacillus acidophilus D11 & $5.13 \pm 0.01^{*}$ & $1.05 \pm 0.02^{*}$ \\
Lactobacillus acidophilus D38 & $5.78 \pm 0.16^{*}$ & $0.55 \pm 0.01^{*}$ \\
Lactobacillus sakei D44 & $5.22 \pm 0.08^{*}$ & $0.86 \pm 0.02^{*}$ \\
Lactobacillus plantarum D70 & $5.62 \pm 0.03^{*}$ & $0.58 \pm 0.05^{*}$ \\
Lactobacillus pentosus D74 & $5.40 \pm 0.07^{*}$ & $0.79 \pm 0.06^{*}$ \\
\hline
\end{tabular}

Data are means $\pm \mathrm{SD}$ from triplicate determinations.

"Significantly differ $(\mathrm{p}<0.05)$ from the control group by Student's t-test.
같다. 대조구의 $\mathrm{pH}$ 와 적정 산도는 각각 $6.92 \pm 0.20$ 및 $0.21 \pm 0.02 \%$ 로 측정된 반면 유산균과의 혼합 배양한 경우 대조구와 유의한 차이가 있었다. L. acidophilus D38과의 혼합 배양 시 $\mathrm{pH}$ 는 $5.78 \pm 0.16$ 으로 가장 높았으나, $L$. acidophilus D11과 혼합 배양했을 때에는 실험구 중에서 가장 낮은 $\mathrm{pH}(5.13 \pm 0.01)$ 를 나타내었다. 적정 산도는 $L$. acidophilus D38 $(0.55 \pm 0.01 \%)$ 및 L. plantarum D70 $(0.58 \pm 0.05 \%)$ 과의 혼합 배양 시 비슷한 수준이었고, $L$. acidophilus D11 (1.05 $\pm 0.02 \%)$ 에 의해서 가장 높은 적정 산도를 나타내었다. 청국장 내 발효 과정 동안 유산균이 증식함에 따라 대사산물인 젖산을 생성함으로써 대조구에 비해 유의하게 낮은 $\mathrm{pH}$ 값과 높은 적정 산도를 나타낸 것으 로 추정된다. $\mathrm{Ju}(31)$ 는 $B$ subtilis $\mathrm{CKB}$ 단독으로 청국장을 제조한 경우 초기 $\mathrm{pH}$ 는 6.5에서 24시간 경과 후 $\mathrm{pH} 7.3$, 96시간 후에는 7.7로 증가되었는데 이는 바실러스균이 증 식하는 동안 암모니아 등의 염기성 물질이 생성되었기 때문 이라고 하였다. 한편, $B$. breve ATCC 15700, L. mesenteroides ATCC 9135 및 L. plantarum ATCC 8014 등의 유산균과 혼합하여 제조한 청국장에서는 초기 $\mathrm{pH}$ 5.0-5.5로 부터 96시간 후 $\mathrm{pH}$ 7.0-7.5로 바실러스균 단독 배양과 유의 한 차이가 없었다. 이는 바실러스균이 유산균의 증식을 억 제하여 젓산의 생성보다 염기성 물질의 생성량이 많았기 때문이라고 하였으나, 본 연구에서는 바실러스균이 유산균 의 증식에 큰 영향을 미치지 않았으므로 이보다 낮은 $\mathrm{pH}$ 가 측정된 것으로 추정된다.

발효 스타터에 따른 청국장의 단백질 가수분해 효소 활 성, 아미노태 및 암모니아태 질소 함량을 측정한 결과는 Table 5와 같다. 대조구의 단백질 가수분해 효소 활성은 $3.39 \pm 0.02 \mathrm{U} / \mathrm{mg}$ 이었으나, 유산균과의 혼합 배양에 의해선 효소 활성이 유의하게 증가되었는데 L. acidophilus D38과 의 혼합 배양 시 $3.86 \pm 0.01 \mathrm{U} / \mathrm{mg}$ 으로 가장 낮았던 반면 L. pentosus D74와의 혼합 배양에 의해선 가장 높은 활성 $(4.89 \pm 0.05 \mathrm{U} / \mathrm{mg})$ 을 나타내었다. $\mathrm{Ju}(31)$ 는 B. subtilis $\mathrm{CKB}$ 단독 배양 시 청국장 내 프로테아제 활성은 $177.5 \mathrm{U} / \mathrm{g}$ 이었 으나 유산균(B. breve ATCC 15700, L mesenteroides ATCC

Table 5. Protease specific activity and amino type nitrogen and ammonium nitrogen contents of Cheonggukjang prepared by the mixed cultures of $B$. subtilis MJ226 and biogenic amine-degrading lactic acid bacteria

\begin{tabular}{cccc}
\hline Biogenic amines-degrading lactic acid bacteria & Protease specific activity (U/mg) & Amino type nitrogen content (mg\%) & Ammonium nitrogen content (mg\%) \\
\hline Control & $3.39 \pm 0.02$ & $258.27 \pm 1.03$ & $286.91 \pm 0.09$ \\
Lactobacillus acidophilus D11 & $4.67 \pm 0.01^{*}$ & $406.71 \pm 2.15^{*}$ & $274.74 \pm 0.04$ \\
Lactobacillus acidophilus D38 & $3.86 \pm 0.01^{*}$ & $348.90 \pm 0.97^{*}$ & $296.81 \pm 0.05$ \\
Lactobacillus sakei D44 & $4.12 \pm 0.03^{*}$ & $389.22 \pm 2.88^{*}$ & $206.35 \pm 0.06^{*}$ \\
Lactobacillus plantarum D70 & $4.44 \pm 0.02^{*}$ & $400.27 \pm 3.05^{*}$ & $202.50 \pm 0.10^{*}$ \\
Lactobacillus pentosus D74 & $4.89 \pm 0.05^{*}$ & $458.61 \pm 2.57^{*}$ & $155.72 \pm 0.06^{*}$ \\
\hline
\end{tabular}

Data are means \pm SD from triplicate determinations.

${ }^{*}$ Significantly differ $(\mathrm{p}<0.05)$ from the control group by Student's t-test. 
9135 및 L plantarum ATCC 8014)과 혼합 배양한 경우에는 136-144 U/g으로 낮아졌다고 하였는데 본 연구 결과와는 차이가 있었다.

아미노태 질소 함량 측정 결과 대조구 $(258.27 \pm 1.03 \mathrm{mg} \%)$ 보다 유산균과의 혼합 배양에 의해 전 실험구에서 유의하게 증가되었으며, L. acidophilus D38(348.90 $\pm 0.97 \mathrm{mg} \%)$ 과의 혼합 배양에 의해 소량 증가된 반면 L. pentosus D74 $(458.61 \pm 2.57 \mathrm{mg} \%)$ 와의 혼합 배양에 의해 가장 많은 양이 증가되었다. 아미노태 질소 함량은 장류의 구수한 맛을 나 타내는 지표로 식품 공전 상에 $0.28 \%$ 이상의 값을 유지하도 록 되어 있는데(32) 본 연구에서는 유산균과의 혼합 배양에 의해 그 기준치를 충족한 것으로 확인되었다. $\mathrm{Ju}(31)$ 는 B. subtilis $\mathrm{CKB}$ 단독 배양 시 청국장 내 아미노태 질소 함량은 $0.44 \%$ 이었으나 유산균(B. breve ATCC 15700, L. mesenteroides ATCC 9135 및 L. plantarum ATCC 8014)과 혼합 배양한 경우 0.46-0.48\%으로 나타나 유산균이 아미노 태 질소 함량 증가에 큰 영향을 미치지 못했다고 하여 본 연구와는 다소 차이가 있었다.

암모니아태 질소 함량은 L acidophilus D11 (274.74 \pm 0.04 $\mathrm{mg} \%)$ 및 L. acidophilus D38 (296.81 $\pm 0.05 \mathrm{mg} \%)$ 과의 혼합 배양 시 대조구(286.91 $\pm 0.09 \mathrm{mg} \%)$ 와 비슷한 수준으로 나타 났으나, L. sakei D44 (206.35 $\pm 0.06 \mathrm{mg} \%)$, L. plantarum D70 (202.50 $\pm 0.10 \mathrm{mg} \%)$ 및 L. pentosus D74 (155.72 $\pm 0.06 \mathrm{mg} \%)$ 에 의해선 유의하게 감소되었다. 따라서 유산균의 단백질 가수분해 효소 생성에 따라 대조구보다 유산균과의 혼합 배양으로 제조한 청국장 내에서 높은 효소 활성이 측정되었 고, 이들의 작용에 의하여 청국장의 주원료인 콩 단백질이 분해됨으로써 아미노태 질소 함량이 대조구에 비해 유의하 게 증가된 것으로 추정된다. $\mathrm{Ju}$ (31)는 B. subtilis $\mathrm{CKB}$ 단독 으로 청국장 제조 시 배양 3 일 경에 암모니아태 질소 함량이 기준치 이상으로 검출되었으나, 유산균과의 혼합 배양 시 에는 5-6일 후 변패 시점에 도달하여 유산균이 저장성을 2 배 가량 연장시켰다고 하였다.

청국장 내 아미노산 및 $\mathrm{BA}$ 함량을 측정한 결과는 Table
6과 같다. 대조구의 리신 및 히스티딘 함량은 각각 $6.3 \pm 0.4$ $\mathrm{mg} \%$ 과 $8.9 \pm 0.2 \mathrm{mg} \%$ 였으나, 이들의 함량은 L acidophilus $\mathrm{D} 38$ 과의 혼합 배양에 의해선 비슷한 수준으로 검출되었으 나, 그 외의 유산균들과 혼합 배양한 경우에는 아미노산의 함량이 유의하게 증가되었다. 한편, 리신의 탈탄산 효소의 작용에 의해 생성되는 카다베린의 함량은 대조구에서 $245.8 \pm 26.1 \mathrm{mg} \%$ 으로 측정되었으며 $L$. acidophilus $\mathrm{D} 11, L$ acidophilus $\mathrm{D} 38$ 및 L. pentosus $\mathrm{D} 74$ 와의 혼합 배양에서도 이와 비슷한 수준의 카다베린이 검출되었으나, L sakei D44

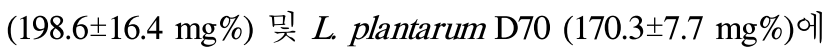
의해선 유의하게 감소되었다. 히스타민의 함량은 $L$. pentosus D74 (400.2 $\pm 8.1 \mathrm{mg} \%)$ 와의 혼합 배양에 의해서 대조구 $(507.2 \pm 28.0 \mathrm{mg} \%)$ 보다 유의하게 낮게 검출되었지 만 그 외의 유산균에 의해선 감소 효과가 나타나지 않았다. 이상의 결과, 카다베린과 히스타민의 전구체인 리신과 히 스티딘은 대조구보다 특정 유산균과의 혼합 배양에 의해 높게 나타났는데 이는 유산균의 항균 물질이 바실러스균의 $\mathrm{BA}$ 생성을 억제함으로써 잔존하는 아미노산의 함량이 증 가된 것으로 보여진다. 게다가 L. sakei D44, L plantarum $\mathrm{D} 70$ 및 L pentosus D74 등의 아민 산화 효소 및 항균 물질 생산에 따라 청국장 내 카다베린과 히스타민의 함량은 대조 구에 비해 낮게 검출된 것으로 추정된다. Capozzi 등(11)은 푸트레신 생성균 L. brevis IOEB 9809 및 티라민 생성균 E. faecium $\mathrm{OT} 23$ 을 $\mathrm{BA}$ 분해능이 있는 L. plantarum $\mathrm{DNT}$ 09 및 NDT16과 혼합한 경우 티라민과 푸트레신의 양은 각각 $29.62 \%$ 와 $38.17 \%$ 감소되었다. 게다가 $\mathrm{BA}$ 분해율의 증가는 L. plantarum의 분해 효소 활성에 기인할 뿐만 아니 라 박테리오신과 같은 항균 물질 생성에 따라 $\mathrm{BA}$ 생성균의 증식을 억제하기 때문이라고 고찰하여 본 연구 결과에서도 이와 유사한 메커니즘으로 $\mathrm{BA}$ 함량이 감소되었음을 추정 하였다. In vitro 상에서 $\mathrm{BA}$ 분해능이 약한 L. hilgardii IFI-CA 41, L plantarum IFI-CA 26 및 $P$. pentosaceus IFI-CA 30 등은 와인 내에서 $\mathrm{BA}$ 함량이 대조구와 거의 유사한 정도로 검출되었으나, $\mathrm{BA}$ 분해능이 강한 L. casei IFI-CA

Table 6. Amino acid and biogenic amine contents of Cheonggukjang prepared by the mixed cultures of B. subtilis MJ226 and BA-degrading lactic acid bacteria

\begin{tabular}{|c|c|c|c|c|}
\hline \multirow{2}{*}{ Biogenic amine-degrading lactic acid bacteria } & \multicolumn{2}{|c|}{ Amino acid contents (mg\%) } & \multicolumn{2}{|c|}{ BA contents $(\mathrm{mg} \%)$} \\
\hline & Lysine & Histidine & Cadaverine & Histamine \\
\hline Control & $6.3 \pm 0.4$ & $8.9 \pm 0.2$ & $245.8 \pm 26.1$ & $507.2 \pm 28.0$ \\
\hline Lactobacillus acidophilus D11 & $9.4 \pm 0.6^{*}$ & $11.2 \pm 0.3^{*}$ & $230.7 \pm 14.0$ & $493.9 \pm 13.4$ \\
\hline Lactobacillus acidophilus D38 & $7.0 \pm 0.8$ & $9.0 \pm 0.1$ & $269.7 \pm 8.7$ & $478.1 \pm 16.9$ \\
\hline Lactobacillus sakei D44 & $8.9 \pm 0.7^{*}$ & $9.4 \pm 0.4$ & $198.6 \pm 16.4^{*}$ & $536.1 \pm 10.5$ \\
\hline Lactobacillus plantarum D70 & $10.7 \pm 0.3^{*}$ & $9.9 \pm 0.2^{*}$ & $170.3 \pm 7.7^{\star}$ & $523.1 \pm 9.7$ \\
\hline Lactobacillus pentosus D74 & $8.8 \pm 0.7^{\star}$ & $14.3 \pm 0.5^{*}$ & $273.4 \pm 11.5$ & $400.2 \pm 8.1^{*}$ \\
\hline
\end{tabular}


52 (히스타민 $54 \%$, 티라민 $55 \%$, 푸트레신 $65 \%$ 분해)를 와인 발효에 이용한 경우 대조구에 비해 유의하게 BA 함량 감소 효과(히스타민 $16 \%$, 티라민 $15 \%$, 푸트레신 $8 \%$ )가 나 타나(10) 분해능이 클수록 BA 함량을 낮추는데 더 효과적 이었고 본 연구 결과도 이와 동일하게 나타났다.

대두 발효 식품마다 BA 함량에 차이가 나는 이유로는 제조 공정 및 환경의 차이에 기인하여 대두에 함유된 단백 질 함량, 발효 스타터의 단백질 가수 분해 활성, 발효 및 숙성 조건, 작업자의 위생적 취급 여부에 따른 아미노산 탈탄산 효소 생성 미생물의 오염 정도에 따라 크게 달라진 다(34). 유해 아민 생성균을 발효 스타터로 사용하거나 발효 과정 중 외부로부터 혼입되어 증식함에 따라 고농도로 축적 된 $\mathrm{BA}$ 를 섭취함으로써 무독화 메커니즘이 작동 불능 상태 가 되어 $\mathrm{BA}$ 에 의한 중독이 유발되기도 하는데 $\mathrm{BA}$ 종류별 중독량에도 다소 차이가 있으나, 일반적으로 BA $100 \mathrm{mg} / \mathrm{kg}$ 이상이면 건강을 위협하기에 충분한 양이다(33). 게다가 식품 내에 여러 종류의 $\mathrm{BA}$ 가 혼재하는 경우 독성이 더 강해지는 것으로 알려져 있는데 예를 들어 푸트레신과 카다 베린은 $\mathrm{DAO}$ (diamine oxidase)의 저해제로서 작용하여 히스 타민 독성의 강도를 더욱 높이게 된다(35). 또한 카다베린과 푸트레신의 함량이 $50-100 \mathrm{mg} / \mathrm{L}$ 정도에 이르면 발효 식품 의 관능학적 품질 특성에 악 영향을 주는 것으로도 알려져 있다(36).

$\mathrm{BA}$ 생성 가능한 식품의 종류가 다양하고 이에 따라 중독 발생 위험도 높아지므로 이를 저감화 시키기 위한 연구가 활발하게 진행되는 가운데 $5^{\circ} \mathrm{C}$ 이하 온도 유지, 보존제와 같은 식품첨가물 사용, 정수압 처리 및 방사선 조사 등 물리 화학적 방법을 주로 적용하였으나, 이들은 식품의 조직감 이나 풍미 저하 및 독성을 유발할 수 있다(36). 이러한 단점 을 보완하기 위해선 발효 식품 제조 시 위생적이고 신선한 원료를 사용하고 발효와 숙성 과정 중 $\mathrm{BA}$ 생성균의 오염을 최소화한 위생적인 제조 공정을 도입해야 하며 아민 산화 효소를 생성하거나 박테리오신 등의 항균 물질을 생산하는 스타터 균주로 대두 발효 식품을 제조할 경우 $\mathrm{BA}$ 으로 인한 위해를 유의적으로 감소시킬 수 있을 것이라고 알려져 있다 (37). 이상의 결과, BA 분해능이 있는 유산균으로 발효 시킨 청국장은 대조구에 비해 $\mathrm{BA}$ 함량이 유의하게 낮은 반면 유리 아미노산의 함량은 높게 나타났으므로 $\mathrm{BA}$ 의 독성 위험을 낮출 수 있을 것이고, 유산균이 증식하는 과정 중 생성한 유기산으로 대조구에 비해 산도가 높아지면 외부로 부터 유입된 오염균의 증식 억제에도 효과적일 것이며 풍미 향상에도 유용할 것으로 판단된다.

\section{요 약}

본 연구의 목적은 메주와 된장으로부터 분리된 바실러스
균과 유산균의 균주별 바이오제닉아민(biogenic amines, $\mathrm{BA}$ ) 생성능과 분해능을 측정하고 바실러스균과 $\mathrm{BA}$ 분해 능이 있는 유산균과의 혼합 배양으로 제조한 청국장의 미생 물학적 및 물리화학적 특성을 조사하는 것이다. 카다베린 $(421.7 \pm 11.0 \mathrm{mg} / \mathrm{L})$ 과 히스타민 $(628.7 \pm 24.1 \mathrm{mg} / \mathrm{L})$ 의 축적은 리신과 히스티딘 탈탄산효소 활성을 나타낸 Bacillus subtilis MJ226에 의해 확인되었다. Lactobacillus acidophilus D11, L. acidophilus D38, Lactobacillus sakei D44, Lactobacillus plantarum D70 및 Lactobacillus pentosus D74 는 카다베린, 히스타민, 푸트레신, 트립타민 및 티라민의 생성능이 없으며, BA 분해능이 높게 나타났다. Lactobacillus sakei D44, Lactobacillus plantarum D70 혹은 Lactobacillus pentosus D74와 B. subtilis MJ226과의 혼합 배양에 의해 제조한 청국장 내에는 유리 아미노산 및 아미노태 질소 함량은 유의하게 증가된 반면 암모니아태 질소 및 $\mathrm{BA}$ 함량 은 감소되었다. 결론적으로 B. subtilis 스타터 균주로 제조 한 청국장 내 $\mathrm{BA}$ 생성은 $\mathrm{BA}$ 분해능을 가진 유산균의 특정 균주에 의해 효과적으로 저해되었음을 확인하였다.

\section{References}

1. Santos MH (1996) Biogenic amines: their importance in foods. Int J Food Microbiol, 29, 213-231

2. Shalaby AR (1996) Significance of biogenic amines to food safety and human health. Food Res Int, 29, 675-690

3. Nout MJR, Ruiker MMW, Bouwmeester HM (1993) Effect of processing conditions on the formation of biogenic amines and ethyl carbonate in soybean tempe. J Food Safety, 13, 293-303

4. Brink B, Damink C, Joosten HMLJ, Huis in'tVeld JHJ (1990) Occurrence and formation of biologically active amines in foods. Int $\mathbf{J}$ Food Microbiol, 11, 73-84

5. Ruiz-Capillas C, Jimenez-Colmenero F (2004) Biogenic amines in meat and meat products. Crit Rev Food Sci Nutr, 44, 489-499

6. Moon JS, Cho SK, Choi HY, Kim JE, Kim SY, Cho KJ, Han NS (2010) Isolation and characterization of biogenic amine producing bacteria in fermented soybean pastes. J Microbiol, 48, 257-261

7. Ibe A, Nishima T, Kasai N (1992) Bacteriological properties of and amine-production conditions for tyramine- and histamine-producing bacterial strains isolated from soybean paste (miso) starting materials. Jap J Toxicol Environ Health, 38, 403-409

8. Maijala RL, Erola SH, Aho MA, Hirn JA (1993) The effect of GDL-induced $\mathrm{pH}$ decrease on the formation 
of biogenic amines in meat. J Food Protect, 56, 125-129

9. Kirschbaum J, Rebscher K, Bruckner H (2000) Liquid chromatographic determination of biogenic amines in fermented foods after derivatization with 3,5-dinitrobenzoyl chloride. J Chromato, 881, 517-530

10. Garcia-Ruiz A, Gonzalez-Rompinelli EM, Bartolome B, Moreno-Arribas MV (2011) Potential of wine-associated lactic acid bacteria to degrade biogenic amines. Int $\mathrm{J}$ Food Microbiol, 148, 115-120

11. Capozzi V, Russo P, Ladero V, Fernandez M, Fiocco D, Alvarez MA, Grieco F, Spano G (2012) Biogenic amines degradation by Lactobacillus plantarum. toward a potential application in wine. Front Microbiol, 3, 1-6

12. Naila A, Lint S, Fletcher G, Bremer P, Meerdink G (2010) Control of biogenic amines in food-existing and emerging approaches. J Food Sci, 75, 139-150

13. Ozogul F, Hamed I (2018) The importance of lactic acid bacteria for the prevention of bacterial growth and their biogenic amines formation: a review. Crit Rev Food Sci Nutr, 58, 1660-1670

14. Joosten H, Nunez M (1996) Prevention of histamine formation in cheese by bacteriocin-producing lactic acid bacteria. Appl Environ Microbiol, 62, 1178-1181

15. Lim ES (2016) Inhibitory effect of bacteriocin-producing lactic acid bacteria against histamine-forming bacteria isolated from Myeolchi-jeot. Fish Aqua Sci, 19, 42-51

16. Lim SM, Lee GJ, Park SM, Ahn DH, Im DS (2006) Characterization of Lactobacillus cellobiosus D37 isolated from soybean paste as a probiotic with anti-cancer and antimicrobial properties. Food Sci Biotechnol, 15, 792-798

17. Lim SM (2009) Characterization of a fibrinolytic enzyme produced by Bacillus subtilis MJ-226 isolated from Meju. Kor J Microbiol, 45, 377-384

18. Lim SM (2014) Heterocyclic amines removal by binding ability of lactic acid bacteria isolated from soybean paste. Kor J Microbiol, 50, 73-83

19. Eerola S, Hinkkanen R, Lindfors E, Hirvi T (1993) Liquid chromatographic determination of biogenic amines in dry sausages. J Assoc Off Anal Chem Int, 75, 575-577

20. Mah JH, Ahn JB, Park JH, Sung HC, Hwang HJ (2003) Characterization of biogenic amine-producing microorganisms isolated from Myeolchi-Jeot, Korean salted and fermented anchovy. J Microbiol Biotechnol, 13, 692-699

21. Lee YC, Lin CS, Liu FL, Huang TC, Tsai YH (2015) Degradation of histamine by Bacillus polymyxa isolated from salted fish products. J Food Drug Anal, 23, 836-844

22. Park SY, Bang MA, Oh BJ, Park JH, Song WS, Choi KM, Choung ES, Boo HO, Cho SS (2013) Fermentation and quality characteristics of Cheonggukjang fermented with Bacillus subtilis BC-P1. Kor J Microbiol, 49, 262-269

23. Shon MY, Kwon SH, Sung CK, Park SK, Choi SD (2001) Changes in chemical components of Chungkugjang prepared with small black bean. Kor J Life Sci, 11, 284-290

24. Lee SY, Park NY, Kim JY, Choi HS (2012) Quality characteristics of rice-doenjang during fermentation by differently shaped meju and adding starter. Kor J Food Nutr, 25, 505-512

25. Rozan P, Kuo YH, Lambein F (2000) Free amino acids present in commercially available seedling sold for human consumption: a potential hazard for consumers. J Agric Food Chem, 48, 716-723

26. Han GH, Cho TY, Yoo MS, Kim CS, Kim JM, Kim HA, Kim MO, Kim SC, Lee SA, Ko YS (2007) Biogenic amines formation and content in fermented soybean paste (Cheonggukjang). Kor J Food Sci Technol, 39, 541-545

27. Gardini F, Ozogul Y, Suzzi G, Tabanelli G, Ozogul F (2016) Technological factors affecting biogenic amine content in foods: a review. Front Microbiol, 7, 1-18

28. Barbieri F, Montanari C, Gardini F, Tabanelli G (2019) Biogenic amine production by lactic acid bacteria: a review. Foods, 8, 17-43

29. Kongkiattikajorn J (2015) Potential of starter culture to reduce biogenic amines accumulation in som-fug, a Thai traditional fermented fish sausage. J Ethn Food, 2, 186-194

30. Leuschner RG, Heidel M, Hammes WP (1998) Histamine and tyramine degradation by food fermenting microorganisms. Int J Food Microbiol, 39, 1-10

31. Ju KE (2008) Study of the quality improvement of Cheonggukjang by application of lactic acid bacteria. MS Thesis. Kongju University, Korea, p25-29

32. Lee GY, Kim SI, Jung MG, Seong JH, Lee YG, Kim HS, Chung HS, Lee BW, Kim DS (2014) Characteristics of Chungkookjang that enhance the flavor and GABA content in a mixed culture of Bacillus subtilis MC31 and Lactobacillus sakei 383. J Life Sci, 24, 1102-1109

33. Fernandez M, Zuniga M (2006) Amino acid catabolic pathways of lactic acid bacteria. Crit Rev Microbiol, 32, 155-183

34. Toro-Funes N, Bosch-Fuste J, Latorre-Moratalla ML, 
Veciana-Nogues MT, Vidal-Carou MC (2015) Biologically active amines in fermented and non-fermented commercial soybean products from the Spanish market. Food Chem, 173, 1119-1124

35. Lehane L, Olley J (2000) Histamine fish poisoning revisited. Int J Food Microbiol, 58, 1-37
36. Alvarez MA, Moreno-Arribas MV (2014) The problem of biogenic amines in fermented foods and the use of potential biogenic amine-degrading microorganisms as a solution. Trend Food Sci Technol, 39, 146-155

37. Hu Y, Xia W, Liu X (2007) Changes in biogenic amines in fermented silver carp sausages inoculated with mixed starter cultures. Food Chem, 104, 188-195 